[Original]

\title{
Bryophyte Communities on the Campus of UOEH and in an Adjacent Natural Forest
}

\author{
Kozue NAKANISHI ${ }^{1}$ and Yuzo Kitazawa ${ }^{2}$ \\ ${ }^{1}$ Plant Ecology Laboratory, Nagasaki University. Nagasaki 852, Japan \\ ${ }^{2}$ Department of Biology, University of Occupational and Environmental Health, Japan. \\ Kitakyushu 807, Japan
}

Abstract: Bryophyte communities were studied at six study sites on and near the UOEH campus in 1981 and 1982. The sites are different in habitat conditions ranging from a little disturbed natural forest of Castanopsis sieboldii, through secondary forest, lawn on slope, lawn on flat site and shrubbery, to cracks between the concrete slabs. The number of bryophyte species decreased, with increasing disturbance, from 23 through 18, 12, 7 and 4 , to 2 in the six study sites respectively. Of the 23 species occurring in the natural forest, 17 were exclusive to the forest site and the remaining 6 were common to the secondary forest. The species occurring on the UOEH campus excepting for those in the secondary forest were the pioneer ones or those which can grow under heavily human impact conditions. They were Bryum capillare, Ceratodon purpureus, Weissia controversa Barbula unguiculata, Bryum argenteum and Brachymenium exile. Bryum argenteum and Brachymenium exile which were distributed even in the cracks between the concrete slabs of the pavement created 3 years ago. In the lawn area, both number of species and abundance are larger on the slope than on the flat site. On the slope, Barbula unguiculata is distributed through a wide range of the environment. But others are abundant on the slope facing the north.

Key words: Bryophyta, ecosystem, succession, human impact, Kitakyushu.

(Received 11 August 1982)

\section{Introduction}

Bryophyte species grow in various ecosystems including urban areas. Species composition and their coverage are different in each ecosystem. With the increase of human impact, bryophyte species tend to become rare. A bryophyte desert is occasionally found in industrial areas.

Kitakyushu City is one of the most famous iron-refinery areas of Japan. The campus of the University of Occupational and Environmental Health, Japan (UOEH) is located at a corner of this industrial area. We selected six minor ecosystem types as study sites for the investigation of bryophyte communities. The aim of this study was to obtain information on the ecology of bryophyte communities in urban areas. 


\section{Study Sites}

We selected the following six minor ecosystem types as study sites. They are different in habitat conditions. The sites are nearly the same as those described in the study of spiders (Okuma \& Kitazawa, 1982) and of Collembola (Tanaka \& Kitazawa, 1982). The vegetation on the UOEH campus was studied by Itow et al. (1981).

1. Natural evergreen broad-leaved forest

This forest is reserved behind an old farmer's house almost in the natural state. The site is on the north-eastern slope of a hill, about $50 \mathrm{~m}$ above sea level, and $7.5 \mathrm{~km}$ southeast of the UOEH campus. It is dominated by about 250-year-old Castanopsis sieboldii accompanied by Symplocos glauca and others. The diameter at breast height of the largest C. sieboldii have attained $100 \mathrm{~cm}$. This forest is a climax one on low hills with mesic yellowish brown forest soil and is one of the representative plant associations in the evergreen broad-leaved forest. The forest floor is dark and covered with fallen leaves and there are only few herbs on it. The study site is on the north-eastern slope of a hill.

2. Secondary mixed deciduous and evergreen broad-leaved forest

A secondary forest consisting of deciduous and evergreen broad-leaved trees remaining on a low hill named Momijigaoka on the UOEH campus. The main deciduous trees are Quercus serrata, Rhus succedanea, Mallotus japonicus and the main evergreen trees are Symplocos lucida, Dendropanax trifidus and Ligustrum japonicum (Itow et al., 1981). Even the biggest trees are less than 30 years in age, smaller than $10 \mathrm{~m}$ in height and smaller than $20 \mathrm{~cm}$ in diameter at breast height.

3 and 4. Lawn areas on the slope and on the flat ground

Two study sites were chosen on the artificial lawn area on the UOEH campus. One is on the slope (3), and another is on the flat land (4). Zoysia japonica, about 5 to $10 \mathrm{~cm}$ high, grows thick in these areas. The lawn was created from 1 to 3 years ago. The ground surface on the northern slope is more humid than on the southern slope and on the flat ground.

\section{Shrubbery}

There are many planted shrubberies on the UOEH campus. Shrub species of the study sites are Pittosporum tobira, Ilex crenata, Eurya emarginata and Rhododendron spp. They are trimmed to $40-60 \mathrm{~cm}$ high. They were planted in the new soil brought there 1 to 2 years ago. 
6. Cracks between the concrete slabs of the pavement

There are cracks between square concrete slabs of the pavement on the UOEH campus. The crack is about $1 \mathrm{~cm}$ wide and $1 \mathrm{~cm}$ deep. The pavement was laid about 3 to 4 years ago.

\section{Methods}

We used quadrats $(15 \times 15) \mathrm{cm}^{2}$ in size for the sampling of bryophytes. In the natural forest, we investigated the bryophyte communities on the bark of trees, on the soil and on the rock. In the secondary forest where there is no rock, we investigated on the bark and on the soil. In other sites, we investigated only on the soil. The degrees of coverage were determined as follows; $100 \%-50 \% \cdots 3,49 \%-10 \% \cdots 2$, less than $10 \% \cdots 1$. Numbers of quadrats used are shown in Table 1.

The presence class of each species was determined according to the percentage of frequency of appearance of the species in total quadrats as follows; $80 \%-100 \% \cdots \mathrm{V}, 60 \%-$ $79 \% \cdots \mathrm{IV}, \quad 40 \%-59 \% \cdots \mathrm{III}, \quad 20 \%-39 \% \cdots \mathrm{II}$, less than $19 \% \cdots \mathrm{I}$, less than $5 \% \cdots \mathrm{r}$ (only when numbers of samples are more than 20). When the number of samples is less than 5 , we write the presence classes in Arabic figures.

The scientific and Japanese names of bryophytes described in Iwatsuki \& Mizutani (1972) are applied in this paper.

\section{Results and Discussion}

Table 1 gives the presence classes of all species. On the basis of this table, ecological features of bryophytes at every study site were elucidated.

\section{Natural forest}

Bryophyte communities were studied on the bark of trees (up to $1 \mathrm{~m}$ from trunk base), rocks and soil. The total number of species was 23. They are commom in the evergreen forest and except for Haplocladium angustifolium do not occur in the places that are greatly influenced by humam impact. The most predominant species was Taxiphyllum subarcuatum which is distributed on the bark, rocks and soil. The predominant species on the bark was Metzgeria conjugata subsp. japonica. Heteroscyphus planus and Isopterygium densum were predominant on rocks. There was moist bare ground on the lower part of a slope, where Hookeria acutifolia, Riccardia planiflora and others which like moist habitat grew.

\section{Secondary forest}

Bryophyte communities were studied on the bark of Quercus serrata (including the 


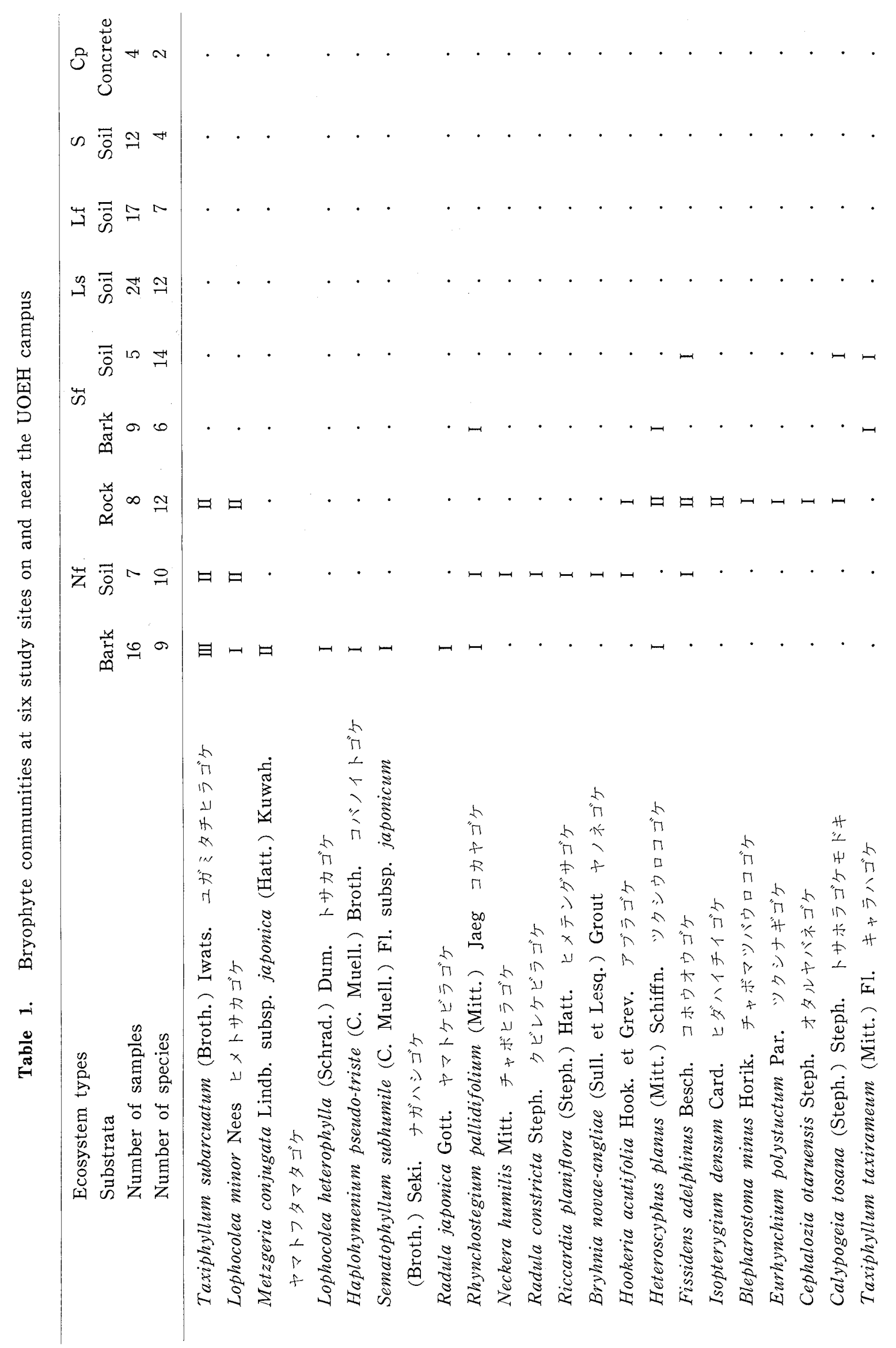




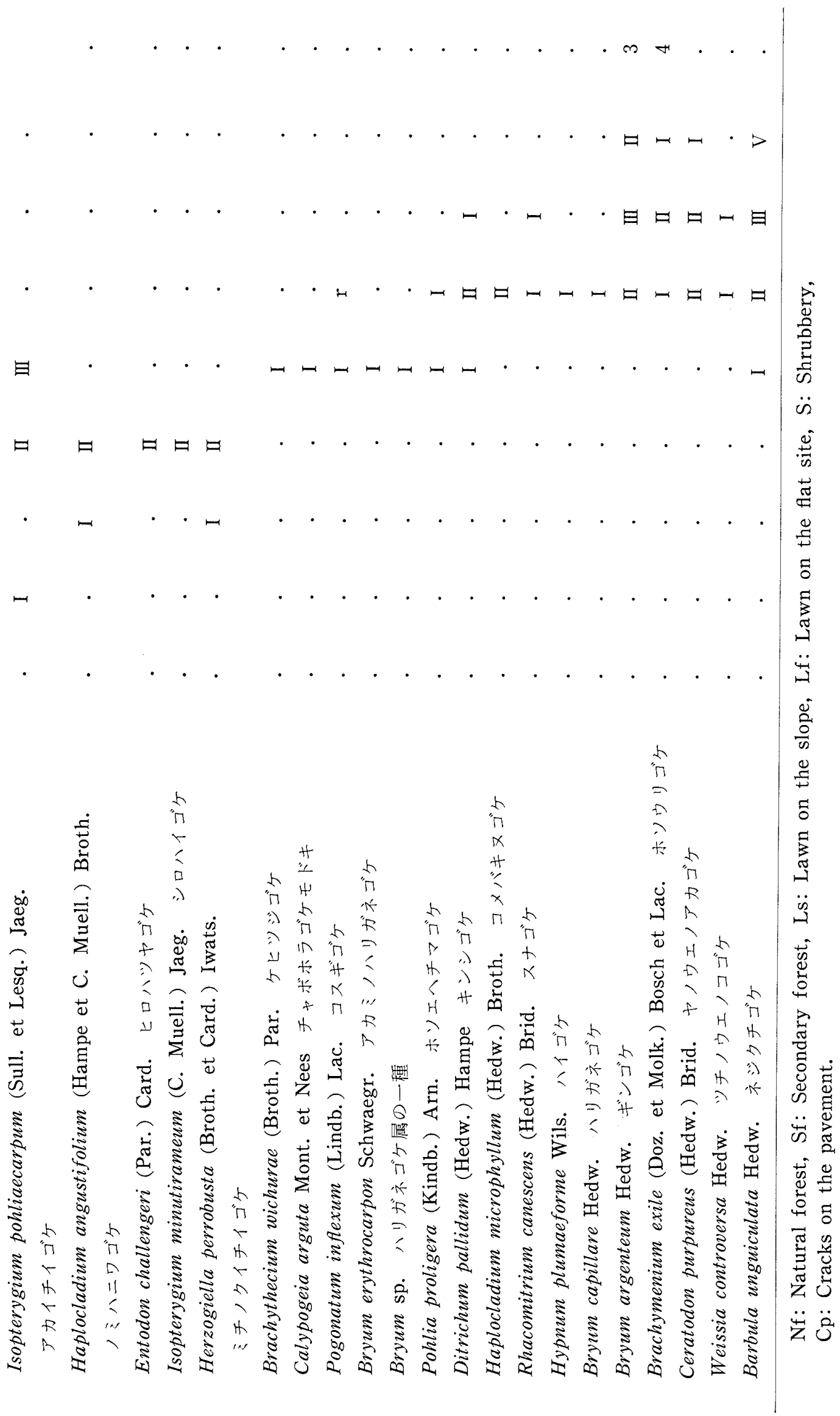


K. Nakanishi \& Y. KitAzawa

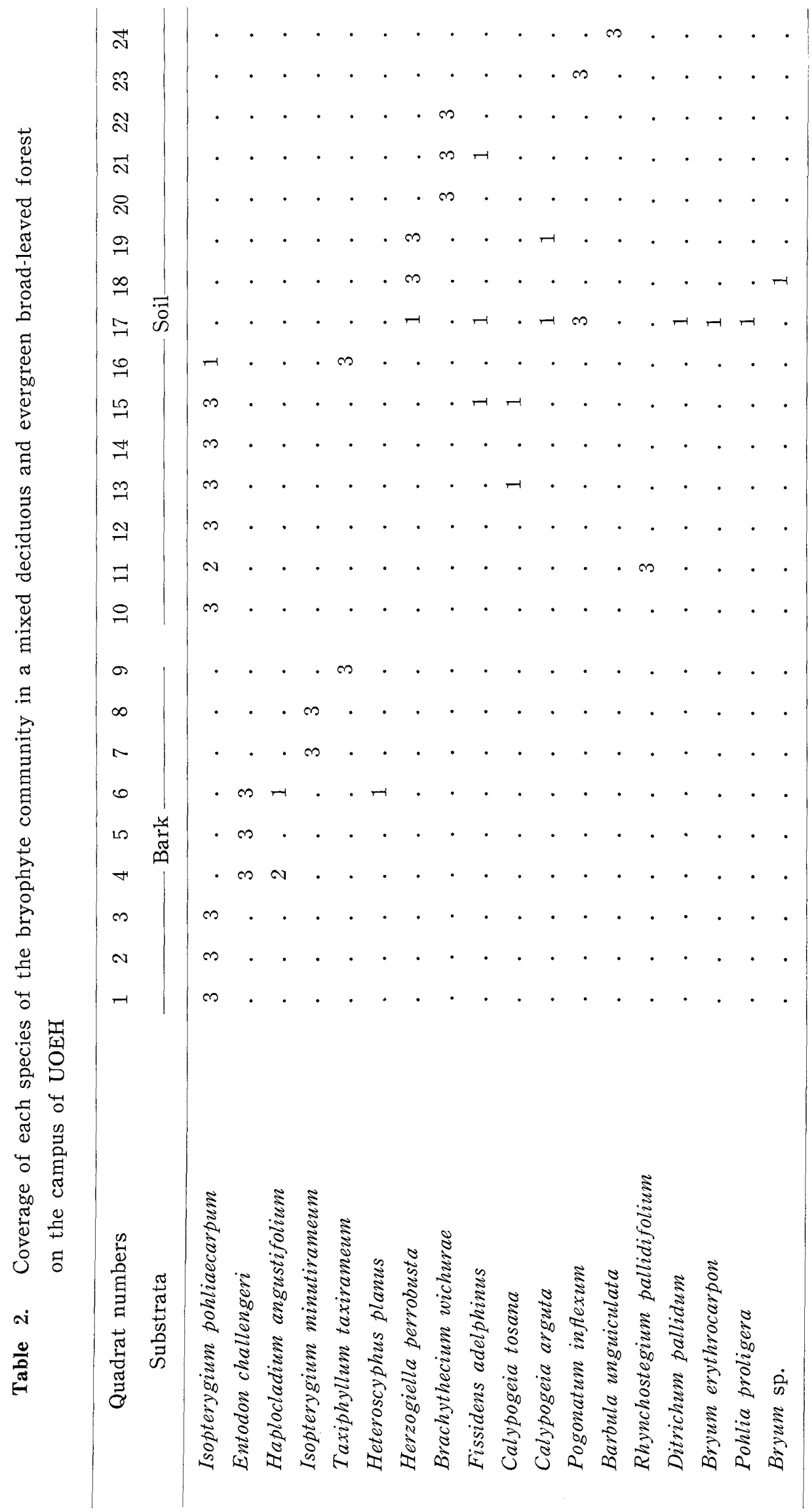


base of stems) and soil of the eastern side of the hill. On the top and western side of the hill bryophytes were rare. The total number of species was 18 . Seven species were common to the natural forest, and the other 11 species were not found there. These are fond of the lighter and drier environmental conditions of the secondary forest. The most predominant species was Isopterygium pohliaecarpum which grows both on the bark and on the soil. The coverage of Entodon challengeri on the bark and Brachythecium wichurae on the soil surface are high (Table 2). The margin of the secondary forest where Pogonatum inflexum and Ditricum pallidum grow, is sunny and light. Barbula unguiculata which grow under conditions greatly influenced by human impact (Nakanishi \& Suzuki, 1977) is also found at the margin.

\section{Lawn area on the slope}

The total number of species is 12 . Bryophytes are usually more abundant on the northern slope than on the southern one. The ground surface of the slope facing the north near the nurses' dormitory and the gymnasium are almost wholly covered with bryophytes. Twelve species are common on the open ground and in the home gardens in other regions. Pogonatum inflexum, Pohlia proligera, Ditrichum pallidum and Barbula unguiculata are commonly found in the lawn area and the edge of the secondary forest. The predominant species are Ceratodon purpureus and Barbula unguiculata which are distributed through a wide range of the lawn area (Table 3).

\section{Lawn area on the flat site}

The total number of species was 7 (Table 4). This site is usually more sunny and drier than the slope, especially the slope facing the north. Both number of species and abundance of bryophytes on the flat site are less than those on the slope. All species which occurred there were common to those on the sloping lawns.

\section{Shrubbery}

The total number of species was 4 . We studied bryophyte communities under the several kinds of shrubberies. But no difference was seen in bryophytic flora with differences in the plant species of the shrubbery. Barbula unguiculata was the predominant species and abundant on the ground shaded by shrubs.

\section{Cracks between concrete slabs of the pavement}

Only Brachymenium exile and Bryum argenteum grow here. The coverage and frequency were higher in the former species than in the latter. These 2 species are representative pioneer plants and grow well on the face of concrete blocks in the city, and are most immune to air pollution (Nakanishi \& Suzuki, 1977; Nehira \& Une, 1981). 

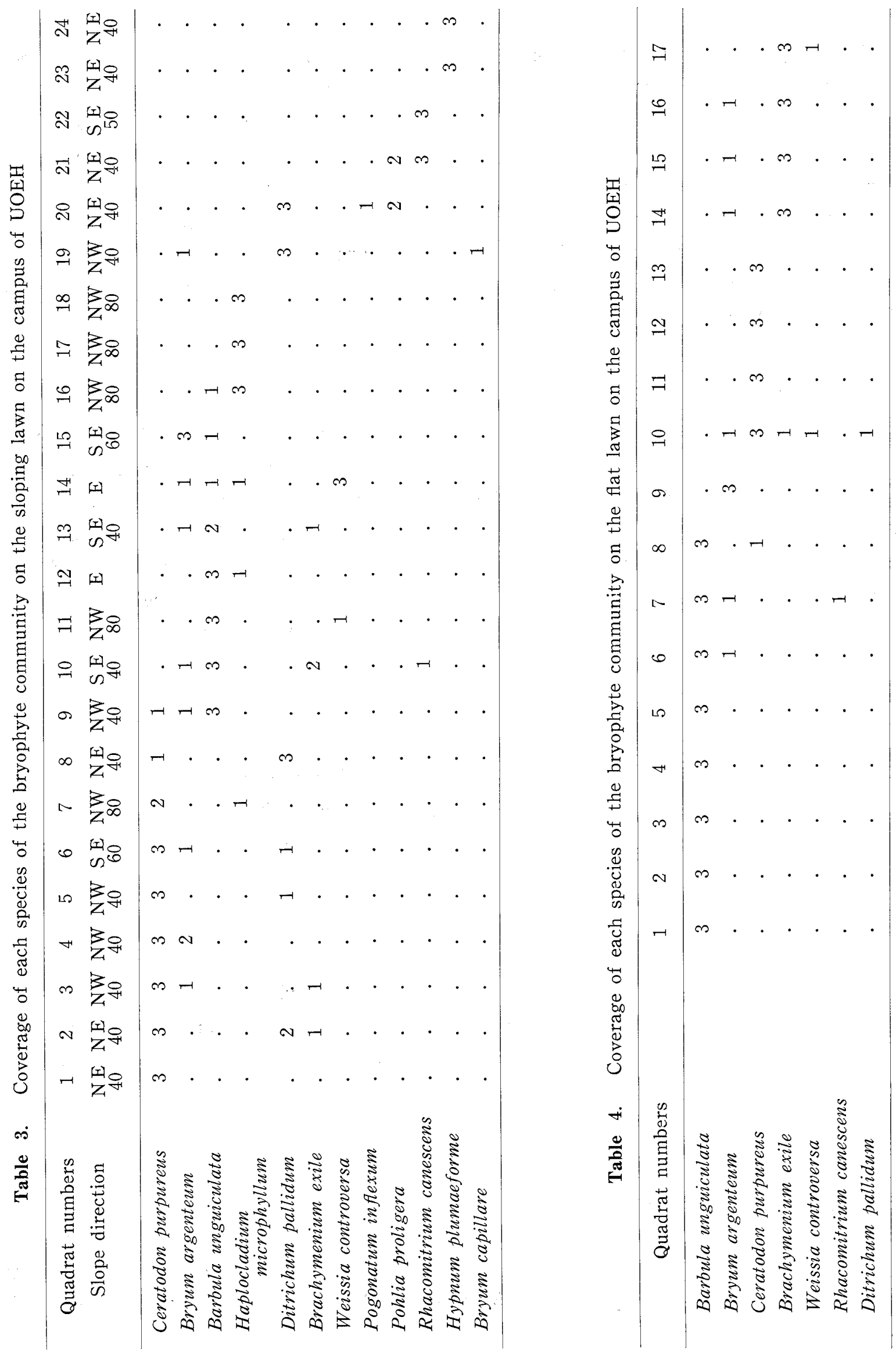


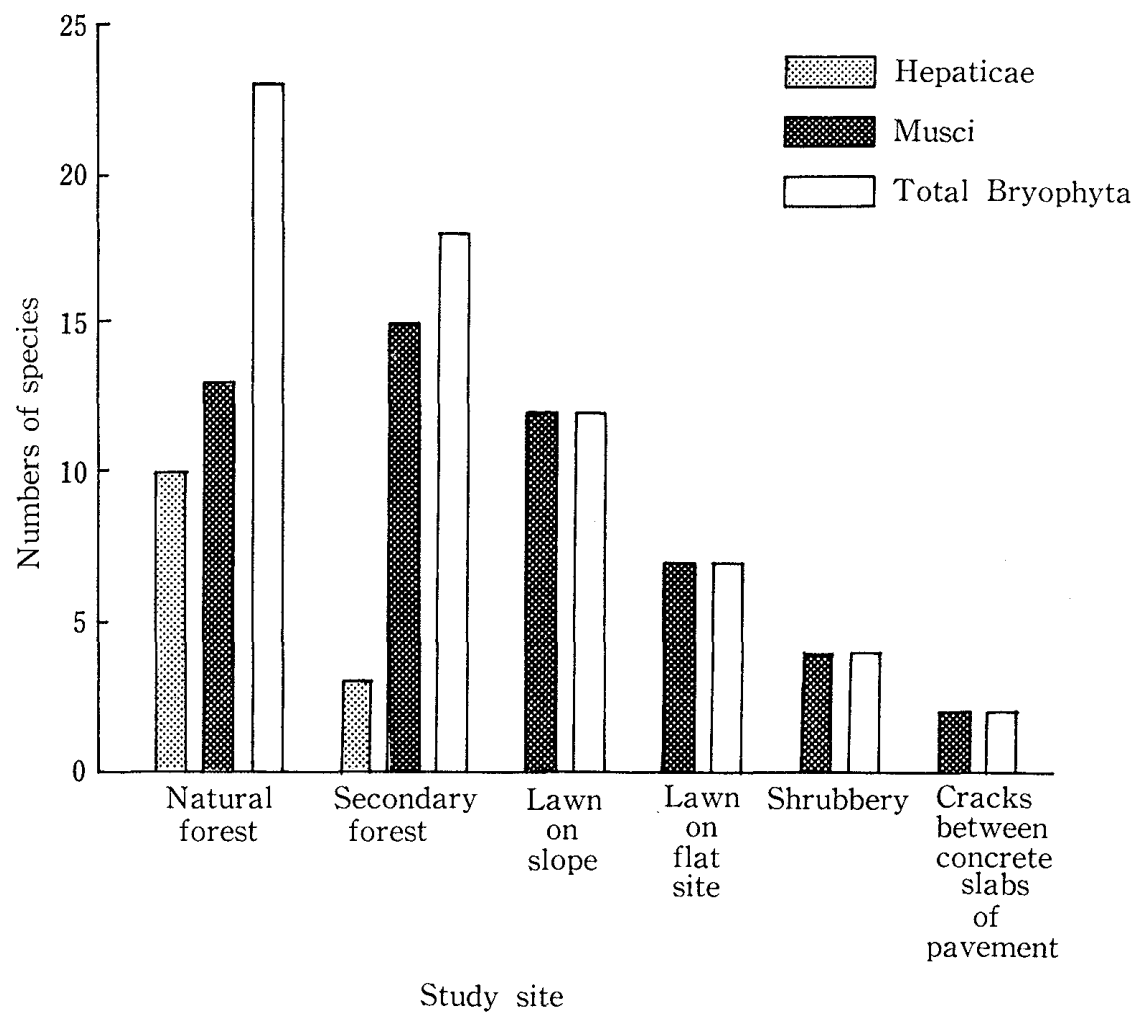

Fig. 1. Numbers of bryophyte species found from six ecosystem types on and near the campus of UOEH.

7. Comparison of bryophytes of six study sites

Fig. 1 shows the number of species of Hepaticae and Musci and total species numbers of Bryophyta. Hepaticae appear only in the natural and the secondary forests and the number of species is larger in the natural forest than in the secondary one. Musci are distributed throughout the study sites, being more in the forest than in other sites. The total number of all bryophytes is the largest in the natural forest, followed by the secondary forest. It is noticeable that it is considerably large on the lawn area on the slope facing the north where a humid condition prevails. In general, it is clear that the number of species of bryophytes in this region is more in the sites where natural conditions are better preserved.

\section{Acknowledgement}

We thank Professor S. Itow of the Plant Ecology Laboratory, Nagasaki University for encouragement in this study and for reading the manuscript. This study was supported by Grant-in-aid No. 56030078 in 1981 for a Special Research Project on Environmental Science, Ministry of Education, Culture and Science, Japan. 


\section{References}

Itow, S., Jinno, N., Kitazawa, Y. et al. (1981): Vegetation of the UOEH campus and its vicinities with reference to conservation of campus environment. J. UOEH, 3: 323-337.

Iwatsuki, Z. \& Mizutani, M. (1972): Coloured Illustrations of Bryophytes of Japan. Hoikusha, Osaka. $405 \mathrm{pp}$.

Nakanishi, K. \& Suzuki, H. (1977): A phytosociological study of bryophyte communities on stone walls and concrete blocks in Hiroshima City. Hikobia, 8: 197-211.

Nehira, K. \& Une, K. (1981): Distribution and ecology of epiphytic bryophytes in urban environments of Hiroshima City. Hikobia Suppl. , 1: 425-429.

Okuma, C. \& Kitazawa, Y. (1982): Spider fauna on the campus of UOEH and in an adjacent natural forest. J. UOEH, 4: 1-9.

Tanaka, S. \& Kitazawa, Y. (1982): A study on Collembola on the campus of UOEH and in an adjacent natural forest. J. UOEH, 4: 313-325.

産業医科大学構内と付近の自然林の蘚苔類の研究

中西てず壳・北沢右三”

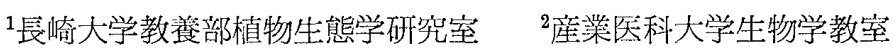

要旨：北九州市の人為による生態系の破壊と再生の系列に沿って 6 種の生態系型を調査地に選び 蘚苔類の種類組成, 常在度, 被度を調べて比較研究した。種数は産業医科大学構内のコン クリート舖装路の割れ目 ( 2 種), 低木の植込み ( 4 種), 平坦地の芝生 (7 種), 敘面の 芝生 (12 種)，構内の二次林 (18 種)，遠賀町のシイ自然林（23 種）の順に增加した. 苔 類は二次林（3 種）と自然林 (10 種) のみに出現した。舗装路の敖れ目にはギンゴケ，ホ ソウリゴケが進入し，植込みと芝生にはそれ以外にハリガネゴケ，ヤノウエノアカゴケ， ツチノウエノコゴケ，ネジクチゴケなどがるられる。てれらは群落遷移における先駆的な 種類であると共に，大気污染などの人為影響にもよく耐えうる。芝生では平坦地よりも， 特に北向きの斜面に種数, 量とも多い. シイ自然林の蘚苔類はその大部分が山地など人為 影響の最も少ない地域に出現する種類である，産業医大棈内では，残存二次林の内に自然 林との共通種が 6 種あったが，それ以外の地域には，シイ自然林との共通種は全く出現し ていない.

J. UOEH（産業医大誌），4(4)：425-434 (1982) 